\title{
Condition, topic and focus in African languages: Why conditionals are not topics.
}

\author{
Bernard Caron \\ LLACAN
}

Since Haiman (1978), a general assumption concerning the information structure of conditional sentences is that "conditionals are topics". However, in Chadic South Bauchi West languages spoken in Northern Nigeria, as well as in Banda Linda, an Adamawa language spoken in the République Centre-Africaine, conditionals share their structure with focus, not topic. This seriously questions Haiman's claim and forces us to reconsider the facts and characterizations of conditionals, topic and focus in general.

In order to do this, we will first examine the facts of conditionals in some Chadic languages, then their information structure. We will see how both data and theory invalidate Haiman's claim. Then we will see that if they are not topics, they are different from focus as well. We will argue that if the elements which make a topic or a focus can appear in conditionals, these must be separated from what constitutes the identity of conditions. Then, we will see if these can be characterized in the same way as Lambrecht characterizes temporal clauses, viz. as "activated propositions" (Lambrecht 1994). We will finally conclude that they should rather be defined as "fictitious assertions" (Culioli 2000).

\section{Introduction}

It is generally assumed, following Haiman (1978) that in the information structure of conditional sentences, conditionals play the role of topics. However, in a few isolated cases, such as the Chadic languages spoken in the South of Bauchi State (Nigeria), henceforth SBW, or Banda Linda, an Adamawa language spoken in the République Centre-Africaine, the marking of conditionals is identical with that of focus. Even if only a few languages are concerned, this brings forward a flaw in the usual analysis of the information structure of conditional systems. Faced with this kind of data, we have to reconsider the analysis of conditionals as topics, and examine precisely the respective properties of topics and foci, and whether they match those of 
conditionals. Actually, conditionals have as many properties in common with antitopics and questions as they have with topics. This leads to the redefinition of the information status of conditionals as frames rather than topics. However, this does not account for the morphological exponents that conditionals share with focus in SBW and Banda Linda. Our hypothesis is that, since focus is a complex operation ${ }^{1}$, conditionals need not share its whole information structure, but may share one of its components, viz. the assertive component. We want to explore the possibility of characterizing conditionals as a type of assertion, viz. fictitious assertions, which may borrow different means of expression such as the assertive component of focus or yes/no question.

\section{Conditional systems}

When two clauses $\mathrm{X}$ (protasis) and $\mathrm{Y}$ (apodosis) entertain a relation, whether conditional or temporal, they form a Conditional System if the existence of $\mathrm{X}$ must be ascertained (whether in reality or in imagination) in order for $\mathrm{Y}$ to be realized. $\mathrm{X}$ is called a conditional clause or conditional.

Generally, Conditional Systems in African languages are not very different from their European counterparts. In $\mathrm{Hausa}^{2}$ for example, the Conditional System is very much like the French or English ones. It follows the order <protasis, apodosis>, <if..., (then)...> under the form <in/idan ..., (sai) $\ldots>$ :

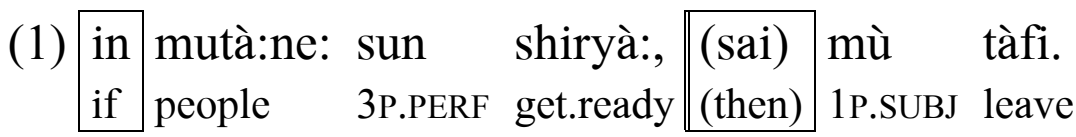 'If people are ready, let's go.' ${ }^{3}$

1 Caron (2000)

2 Our Hausa examples are borrowed from Jaggar (2001) and Newman (2000). The African languages quoted in the article are tone languages. High $(\mathrm{H})$ and Low $(\mathrm{L})$ tones are transcribed respectively by acute (á) and grave (à) accents. Falling (F) and Rising (R) tones are marked respectively by a circumflex accent (â) or a chevron (ă). Length in vowels is marked by a colon.

3 Abbreviations:

1,2,3, person; ACC, completed; ANAPH, anaphora; COMP, complementizer; COND, conditional; CONT, continuous; COP, copula; DEICT, deictic; DUR, durative; FOC, focus; FOCS, subject focus; FUT, future; GL, genitive link; IMPERF, imperfective; INCH, inchoative; INJ, injunctive; IRR, irrealis; MID, middle; NEG, negation; P, plural; PERF, perfective; POS, positive; PUNCT, punctilliar; REL, relative pronoun; s, singular; SUBJ, Subjunctive; TAM, Tense-Aspect-Mood; vN, verbal noun. 
However, one difference arises from the relationship between temporal clauses and the potential, temporal and irrealis readings of conditional clauses. It is most common in European languages to find a morphological difference drawn between conditional clauses introduced by if (English) or si (French) and temporal clauses introduced by when (English) or quand (French). Then the TAM in the conditional clause may introduce a further difference beween the potential and irrealis readings of the conditional such as English If you come, I will pay you. (potential) and If you had come, I would have paid you. (irrealis).

The situation is different in the African languages studied here. In Hausa for example, the conditionals introduced by in, 'if' can have both a temporal and a potential reading but cannot have an irrealis reading.

Hausa Conditional Clause: potential reading

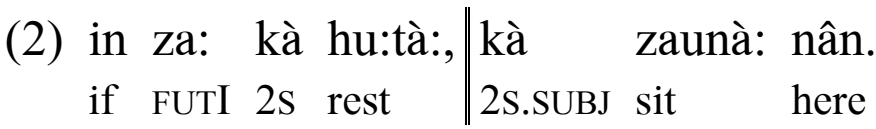
'If you want to rest, sit here.'

Hausa Conditional Clause: temporal reading

(3) in mun gamà cî-n àbinci|lsai mù fita ya:wò:. if 1P.PERF finish eat-GL food then 1P.SUBJ go out stroll 'When we have finished eating, we'll go for a walk.'

The irrealis hypothesis where the protasis expresses a counterfactual past event uses a construction different from the Conditional System, involving a discontinuous morpheme dà: ... dà::

(4) dà: sun tàimàke: mù, dà: mun gamà:. IRR 3PERF help 1P IRR 1P.PERF finish

'If they had helped us, we would have finished.'

We will now proceed to study the informational structure of conditionals. 


\section{Conditionals and topicality}

\subsection{Haiman: Conditionals are topics}

In his seminal 1978 paper $^{4}$, Haiman compares Conditional Clauses to topics: they have the same distribution at sentence initial position and the same information status.
“[...] conditionals are topics (= givens, presuppositions) of their sentences, [...] (Haiman 1978: 567). The topic represents an entity whose existence is agreed upon by the speaker and his audience. As such, it constitutes the framework which has been selected for the following discourse.” (Haiman 1978: 585)

In South Bauchi Chadic languages, this seems to be confirmed by the existence of paratactic Conditional Systems where the Conditional Clause appears like an unmarked topic. The conditional readings are inferred from the mere juxtaposition of protasis and apodosis:

Zaar $^{5}$ : paratactic Conditional System; potential reading

[Context : in this traditional riddle, the narrator asks the hearers to solve the following problem: how do you take a hyena, a goat and beans across a river on a boat that can only take two at a time?]

(5) kyá: mbí: ma:t,

2S.IMPERF take goat

kə ga: mbárgə̀ptə̧ dađáni tá zà:m.

2S.SUBJ leave hyena there with beans

'If you take the goat, you leave the hyena with the beans.' (Caron 2005)

4 Haiman, John. 1978. Conditionals are Topics. Language 54: 564-589.

5 Zaar, Zodi and Polci are South Bauchi West (SBW) languages spoken in Northern Nigeria, dominated and endangered by Hausa. They belong to the same West branch of Chadic languages as Hausa. 
Zodi: paratactic Conditional System; iterative/habitual reading

[Context : A chief narrates his role in former local wars.]

$\begin{array}{lll}\text { (6) áma: } & \text { wu } & \text { ya:kón yak } \\ \text { 1S.IMPERF } & \text { say } & \text { saliva }\end{array}$

to: man tfí-ni gálba a bət 'yeróm ma:nti gəm.

well 1P.FUT eat-MID victory at on friend war 1P.POSS

'When I bless them, we beat our enemies.' (Caron 2002)

Topics can be multiple, and likewise Conditional Clauses. See the following examples in Zaar.

Zaar multiple Conditional Clauses

(7) kúmá tsátn-kónì-atn dangəní,
also live-vN-1s.POSs now

'As for my life today,'

\begin{tabular}{llll||} 
ló:kací & yó:dạ & mi-ká & tsátn-kónì, \\
time & REL & 1s-CONT & live-VN
\end{tabular}

'what I live today,'

\begin{tabular}{llllll||} 
ra: & wum-kónì & gòtn & day & á-tâ-yá: & wum \\
heart & feel-vN & 1S.POSS & REL & 3s-PAST3-IMPERF & feel
\end{tabular}

'the sadness I used to feel'

\begin{tabular}{lllll||} 
á-tá-yi & tu & murkádə̀n-atn & tà & məs-í: \\
3s-PAST3-PUNCT & COMP & husband-1s.POSS & PAST3 & die-ACC
\end{tabular} '(because) my husband had died,'

tô: ra:-atn bà: á-tâ-yá: mbút da gì:ri hón,

well heart-1S.POSS NEG 3S-PAST3-IMPERF rest at well NEG

'well, I was not happy,'

àmmá: dangəní râ:s à: mbút-ni.

but now heart.ANAPH 3s.PERF rest-INCH

'but now I am happy.' (Caron 2005) 
[Context : A butcher boasts of being able to drink and go on working without getting drunk.]

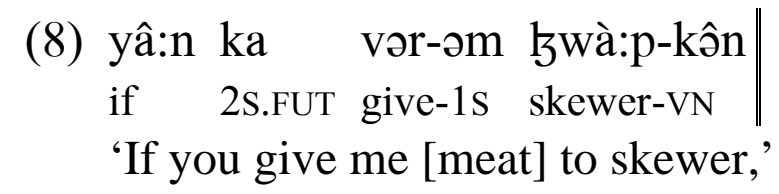

kyá: jòm tû:-wà: an ni:

2S.IMPERF pile meat-3s.POSS like what

'if you pile up a huge amount of meat,'

\begin{tabular}{lllll||} 
myá: & tyá & jíkô & á & bân-í \\
1S.IMPERF & drink & beer & 3s.SUBJ & finish-ACC
\end{tabular}

'if I drink a lot of beer,'

$\begin{array}{llll}\text { wàllây } & \text { ma } & \text { 3wá:p-í } & \text { swâtswât. } \\ \text { oath } & \text { 1s.FuT } & \text { skewer-ACC } & \text { perfectly }\end{array}$

'I swear I will skewer [the meat] perfectly.' (Caron 2005)

\subsection{Conditional clauses are not presupposed topics}

First, let us remove a small problem which arises from the characterization given by Haiman in terms of truth value:

"[...] topics, like conditional clauses, are presuppositions of their sentences. [...] For an NP, it is the EXISTENCE of its referent which is presupposed. [...] For an S, however, it is the TRUTH of the proposition of the sentence which is presupposed." (Haiman 1978: 585f., original emphasis)

The definition of presupposition in terms of truth value is the first problem with Haiman's characterization of conditionals. The concept of truth value borrowed from the world of mathematical logic refers to a stable and objective referent, to a state of affairs than can be verified by everyone. When dealing with the information structure of natural languages, we must provide a means to account for activities whose referents do not exist in external reality, such as lies, imagination, etc.

Lambrecht (1994) avoids this problem when he redefines a number of concepts in terms of information structure by using the notion of 'state of mind of the speakers', as it is expressed in utterances, without involving the extra- 
linguistic dimension. His definitions of topic and presupposition (as opposed to assertion) are as follows:

- Topic expression

"A constituent is a topic expression if the proposition expressed by the clause with which it is associated is pragmatically construed as being about the referent of this constituent.” (Lambrecht 1994: 131)

- Pragmatic presupposition

"The set of propositions lexicogrammatically evoked in a sentence which the speaker assumes the hearer already knows or is ready to take for granted at the time the sentence is uttered." (Lambrecht 1994: 52)

- Pragmatic assertion

"The proposition expressed by a sentence which the hearer is expected to know or take for granted as a result of hearing the sentence uttered.” (Lambrecht 1994: 52)

If we combine these definitions with Haiman's claim, Conditional Clauses are still characterized as (presupposed ${ }^{6}$ ) topics, falling outside the scope of the assertion. We will see that Conditional Clauses share properties with questions and antitopics which makes them incompatible with this status of presupposed topics.

\subsubsection{Conditional clauses and questions}

Haiman notices the affinities between conditionals and Yes/No questions, and gives the following examples where a Conditional Clause can be glossed by a question:

"Is any among you afflicted? Let him pray.” (Haiman 1978: 570) If any among you is afflicted, let him pray.

6 In our own terminology, we would use the term "preconstruct" rather than presupposition.

Cf. (Caron 2000). 
Likewise, Frajzyngier (1996) states that morphemes marking condition and Yes/No questions are often related in Chadic, to the extent that he thinks the former are derived from the latter.

This points in a new direction for conditionals. Questions are not presupposed, they are a different type of assertion: they are not asserted as regards polarity: the speaker is unable to do so, and resorts to the co-speaker to assert the corresponding proposition. In the case of Yes/No questions, the proposition is neither presupposed, nor asserted positively or negatively. We want to argue that the status of Conditional Clauses is, to a certain extent, similar to that of those questions.

\subsubsection{Conditional clause and antitopics}

Conditional Clauses can occur in the same position as antitopics:

Postposed Hausa virtual Conditional Clause

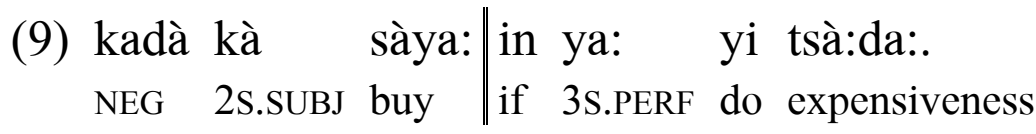

'Don't buy [it] if it is [too] expensive.'

Postposed Hausa habitual Conditional Clause

(10) ta-kàn gan shì in ta: je: kà:suwa:

3S-HAB see 3s if 3S.PERF go market

'She always sees him when she goes to the market.'

Antitopics have a different information function from topics: as afterthoughts, antitopics are used to add some information to utterances that are usually incomplete. If Conditional Clauses have the same function as antitopics, they convey some kind of unshared knowledge that is subject to some sort of assertion.

Given the fact that the information function of Conditional Clause is not different, whether they appear on the left or the right of the main clause, we want to argue that Conditional Systems are complex utterances articulating two propositions which entertain a relation different from that of topic-comment, while each of them has its own type of assertion. 


\subsection{Conditional clauses are frames}

Broadly speaking, conditionals belong to the same syntactic class as adverbial clauses. We have seen in ex. (3) that conditionals can have a temporal reading, and this ambiguity is commonly tolerated in Hausa, whereas counterfactual hypotheses are specifically marked with the discontinuous marker dà: ... dà: (cf. ex.. 4 above).

Both adverbial and Conditional clauses appearing in the left periphery of the sentence have to be distinguished from the topic proper. We owe the proof that this left periphery has its own complex structure to Morel and DanonBoileau (1998, 1999). It is called the 'preamble' when it is associated with a predication which functions as a rheme. Within the preamble, the 'topic' has to be distinguished from the 'frame'. The topic is a referential construct which will become an argument of the rheme; the frame is the area in which the predication holds true. Conditionals and initial adjuncts are just different types of frames.

\subsection{Conditional clauses and activated propositions}

Lambrecht (1994) notices that initial adverbial clauses in English bear a special type of stress. Now, in English, stress has always been associated with focus while topics are never focussed. Stress indicates the existence of an assertionbearing element, whereas the topic is not asserted. Lambrecht interprets this stress as a mark of reactivation :

"the function of the accent is to reactivate the referent of the presupposed proposition and to announce its role as a scenesetting topic for the main-clause proposition.” (Lambrecht 1994: 219)

However, not all adverbial clauses are presupposed, and conditionals are not, as we have seen above. In the same way that initial adverbial clauses in English seem to share stress with focus, some African languages seem to have a common structure for Conditional Clauses and focus.

\section{$4 \quad$ Conditionals and focus}

\subsection{Polci (SBW; Northern Nigeria)}

In Polci, a Chadic language of Northern Nigeria, focussed constituents and Conditional Clauses appear on the left periphery marked by the idenfifying copula kan, 'it is'. 
Focus \begin{tabular}{lll|llll} 
(11) & wún & gi & kən & yu nen a ga: & gi. \\
girl & DEICT & COP & pour milk in calabash & DEICT
\end{tabular} 'THE GIRL poured milk into the calabash.'

Conditional

(12) Gărbà kən nogay to: wú de kə fǔ:-m. Garba COP cut meat ACC INJ 2s.sUBJ tell-1s

'If Garba slaughters an animal (lit. GARBA slaughters an animal), tell me.'

\subsection{Zodi (SBW ; Northern Nigeria)}

The same applies to Zodi, another Chadic language of the same area, where the identifying copula is si. The following example has an ambiguous reading between conditional and focus :

(13)

\begin{tabular}{|l|lllll}
\hline són & si & ní: rós-ti re: mół ma:yti a ga eróm ma:yti. \\
3P & FOC & FUT leave-3P go take war at near thing.of war
\end{tabular}

'THEY will go and fight the enemies. If/when they go, they fight the enemy.'

In the following Conditional System, the protasis could be an autonomous utterance with the reading 'THEY (are the ones who) will follow them.':

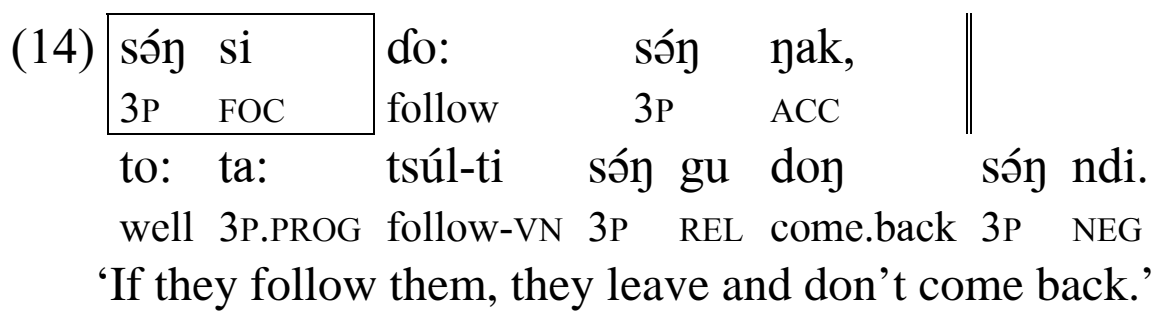

\subsection{Banda Linda (Adamawa, RCA)}

This phenomenon is not limited to these few Chadic languages. It was first noticed in Banda-Linda - an Adamawa language spoken in RCA - by France Cloarec-Heiss (1982, 1995, 2000).

The "usual" Conditional System of Banda-Linda uses àdá, 'if' to introduce the protasis, and the verb of the protasis is prefixed with $k \grave{\partial}$-. 

(15)

\begin{tabular}{|c|c|}
\hline dá gbàlákà & kò-ká \\
\hline & COND-PERF.is_finished \\
\hline $\begin{array}{ll}\text { njā vôtó-wà } \\
\text { ne }\end{array}$ & $\begin{array}{ll}\text { ónú } & \text { nə̀. } \\
\text { sesame } & \text { the }\end{array}$ \\
\hline
\end{tabular}
'When the tray is finished, one starts cutting the sesame.' (Cloarec- Heiss 1986)

Another strategy uses the same markers as focus. In Banda-Linda, when a constituent is focussed it is fronted and followed by k̇̀ when it is the subject and dá when it has another syntactic function:

(16)

\begin{tabular}{|c|c|}
\hline $\begin{array}{ll}\bar{\partial} \mathrm{m} \bar{\partial} & \frac{k \grave{\partial}}{\text { FOCS }}\end{array}$ & $\begin{array}{ll}\text { zá sóngbã } & \text { án } \\
\text { ACC eat } & \text { meat }\end{array}$ \\
\hline
\end{tabular}

'I (am the one who) ate the meat.' (Cloarec-Heiss 2000)

The same structure can be observed for the Conditional System. Compare examples (18) and (19) where the Conditional Clause in (19) can stand on its own as an utterance where the subject àbà is focussed:

(17) ว̀bว̀ kà gbôgbô.

you FOCS DUR.is_strong

'You are the strongest.'

\begin{tabular}{rl|llll} 
(18) àbà & $k \grave{\partial}$ & gbôgbô & bà zá & ngá zò gáfú. \\
you & FOCS & DUR.be_strong & you & PERF.put friend_of you out
\end{tabular}

'If you are strong, you throw your friend out.' (Cloarec-Heiss 2000)

\subsection{Is the conditional clause the focus of the conditional system?}

If conditional clauses are not topics, they are not focuses either. Lambrecht defines focus as "the semantic component of a pragmatically structured proposition whereby the assertion differs from the presupposition” (1994: 213). In a focus structure, the focussed argument is asserted, whereas the predication is presupposed, or preconstructed, following Caron's (2000) terminology. If the Conditional Clause (protasis) were the focus, that would make the apodosis the presupposition of the Conditional System. Now, as we saw above, both apodosis and protasis are asserted. This means that the identification which functions both in focus and conditional structures has to be accounted for in a different way.

In Banda-Linda, the identification marker can have a thetic reading inside a presentational structure. This is the case in ex. (19) below where the narrator introduces himself at the beginning of his tale. 
(19)

\begin{tabular}{llllll|l}
\hline ग̄mō méyā & nó & ngònjēnó & kò & só, & Pá pà \\
I & Méya & from & Ngonjeno & FOC.S & COP \\
then & say \\
cémà & mō & kó & & & \\
speech.of & me & ANAPH
\end{tabular}

'I am Méya of Ngonjeno [lit. It is I, M. of N.], I will tell you a story [of my own].' (Cloarec-Heiss 2000).

(19) can be compared to the following French example where the identifier (c'est..., 'it is') introduces the protagonist of a story:

(20) $\mathrm{C}^{\prime}$ est Toto qui rentrait de l' école... it is Toto who come_back.IMPERF from the school 'It's (the story) of Toto who was coming back from school.'

In examples (19) and (20), neither of the identified elements (Meya of Ngonjeno or Toto) is focussed. The sentences consist of two predications that are both asserted, and the information value of the first predication is thetic.

Our hypothesis is that the same type of thetic identification is used in Conditional Clauses, making them work as a frame for the following apodosis.

"With 'if', the existence of $\mathrm{p}$ [protasis] is constructed in relation with a second term, $\mathrm{q}$ [apodosis] consequent to the first. The result is a chaining relation ( $p$ implies $q$ : if $p$, then q) where nothing is said about p' (complementary of p)." (Culioli 1999: 179).

If they are a frame, what type of frame are they, and the result of what type of assertion?

\section{$5 \quad$ Conditionals are fictitious assertions}

From the point of view of assertion, the protasis is a fictitious assertion, i.e. " asserted from a subjective imaginary locator, detached from the present enunciator, and enabling a complex representation. " (Culioli 1999: 160). The Conditional Clause is a fictitious frame belonging to the preamble.

The constuction of this fictitious frame is compatible with different syntactic structures such as parataxis, thetic identification, or specialized conjunctions like English if, or Hausa in, Banda ̀̀dó. However, within the Conditional Clause, topic and focus structures can be used to build an information layering where these structures are used as a foundation for the making of the Conditional Clauses which, itself, does not work as a focus or a 
topic, but as a referential frame, detached from the actual assertion situation (hic et nunc). This detachment explains the production of different referential values: temporal, habitual, future, irrealis (with the addition of specific morphemes).

The same process is used when asking a yes/no question. A yes/no question is not asserted from the point of view of polarity. The suspension of polarity has to do, from a cognitive point of view, with the fictitious assertion at work in Conditional System. Both are detached from the hic et nunc of straight assertion. This could explain the common morphological origin of yes/no question words and protasis markers in Chadic. (Frajzyngier 1996). 


\section{References}

Caron, B. (2000) Assertion et préconstruit: topicalisation et focalisation dans les langues africaines. In: B. Caron (ed.) Topicalisation et focalisation dans les langues africaines. Louvain: Peeters, 7-42.

Caron, B. (2002) Dott, aka Zodi (Chadic, West-B, South-Bauchi): Grammatical notes, vocabulary and text. Afrika und Übersee, 85: 161-248.

Caron, B. (2005) Za:r (Dictionary, grammar, texts). Ibadan (Nigeria): IFRA.

Cloarec-Heiss, F. (1982) Emphase et condition en banda-linda. Bulletin de la Société de Linguistique de Paris, 77: 365-375.

Cloarec-Heiss, F. (1995) Le banda-linda. In: R. Boyd (ed.) Le système verbal dans les langues oubanguiennes. München, Newcastle: Lincom Europa, 81-112.

Cloarec-Heiss, F. (2000) Focalisation et topicalisation en banda-linda. In: B. Caron (ed.) Topicalisation et focalisation dans les langues africaines. Louvain: Peeters, 45-72.

Culioli, A. (1999) Pour une linguistique de l'énonciation 2 - Formalisation et opérations de repérage. L'homme dans la langue, Paris: Ophrys.

Frajzyngier, Z. (1996) Grammaticalization of the Complex Sentence. A case study in Chadic. Studies in Language Companion Series (36), Boulder: Boulder University.

Haiman, J. (1978) Conditionals are Topics. Language, 54: 564-589.

Lambrecht, K. (1994) Information structure and sentence form: topic, focus, and the mental representations of discourse referents. Cambridge studies in linguistics (71), Cambridge England, New York: Cambridge University Press.

Morel, M.-A., \& L. Danon-Boileau (1998). Grammaire de l'intonation. L'exemple du français. Bibliothèque de Faits de Langues, Gap, Paris: Ophrys.

Morel, M.-A. \& L. Danon-Boileau (1999) Thème, préambule et paragraphe dans l'oral spontané en français. In: C. Guimier (ed.) La thématisation dans les langues. Actes du colloque de Caen, 9-11 octobre 1997, Bern: Peter Lang, 359-377. 